\title{
Peacebuilding and the Interface of State Law and Indigenous Market Laws in Southern Nigeria
}

\author{
Anthony C Diala (1)* \\ University of the Western Cape \\ adiala@uwc.ac.za
}

\begin{abstract}
How the interface of state law and indigenous market laws contributes to peacebuilding in Nigeria is an unexplored question that demands attention. First, law, human security and peace are interrelated through the cultural ideas and norms that inform human behaviour. Second, the co-existence of normative orders in Africa favours a top-down approach that inadequately acknowledges indigenous law, neglects its economic, cultural and religious influences, and thereby affects human security. Based on key informant interviews, focus group discussions and observation of markets in southern Nigeria, this article finds that although indigenous market laws are much altered, their foundational values inform market union constitutions, bye-laws and dispute resolution mechanisms. Union officials draft these laws with the assistance of Western-trained legal practitioners and apply them in close co-operation with state organs, who recognize market tribunals as quasi-judicial bodies. The article urges policy attention on the manner people adapt indigenous market laws to socio-economic changes.
\end{abstract}

\section{Keywords}

Bottom-up peacebuilding, state law, indigenous market laws, legal pluralism, Nigeria

\section{INTRODUCTION}

Indigenous law regulates the lives of the majority of people in sub-Saharan Africa and studies have shown that indigenous legal orders possess efficient peacebuilding mechanisms. ${ }^{1}$ These mechanisms are rooted in local

Senior lecturer, University of the Western Cape, South Africa. I wrote this article as a guest researcher at the Nordic Africa Institute, Uppsala, Sweden, from April to June 2018. I acknowledge the financial assistance of the University of Cape Town, South Africa, where I was a URC postdoctoral fellow at that time.

1 K Werner "Rediscovering indigenous peacebuilding techniques: the way to lasting peace?" (2010) 3/2 Africa Peace and Conflict Journal 60; AG Adebayo et al Indigenous Conflict Management Strategies in West Africa: Beyond Right and Wrong (2014, Lexington Books). Indigenous law is used here in a plural and singular sense. It is also referred to as customary law, "people's law", "folk law" and "traditional law". For varying terminologies, see A Allott and GR Woodman People's Law and State Law: The Bellagio Papers (1985, Foris Publications). 
institutions with an evolutionary history suited to changing cultural, religious, legal and economic conditions. ${ }^{2}$ As a platform for trade and dispute resolution, market laws feature prominently in the evolution of indigenous peacebuilding mechanisms. These laws demand attention for two reasons.

First, the transmogrification of European laws into state laws altered many aspects of indigenous law in Nigeria and other African countries. ${ }^{3}$ This alteration occurred alongside the marginalization of indigenous legal systems in favour of transplanted European laws. ${ }^{4}$ The marginalization of indigenous law is evident in judicial decisions that strike down indigenous laws for incompatibility with constitutional bills of rights. It is also evident in evidentiary rules that require indigenous law to be proved as fact, and in judicial institutions, which are configured to distrust oral narratives, which, ironically, constitute the bulk of indigenous law. Second, law, broadly conceived, is a tool of social engineering that is intrinsically linked to the socio-economic factors surrounding human security. ${ }^{5}$ In this context, peacebuilding discourse will benefit from a nuanced explanation of the relationship between state law and indigenous norms of commerce. ${ }^{6}$ These norms, which I also refer to as indigenous market laws, embrace remnants of trade principles and obligations from the precolonial era.

So, in what ways does the interface of state law and indigenous market laws in southern Nigeria contribute to peacebuilding? I argue that peacebuilding will be more effective if policies on the interaction of indigenous law and state law focus on the manner people adapt indigenous laws to cultural, legal, religious, political, and economic changes in social fields. ${ }^{7}$ This adaptation framework of normative interaction operates on the foundational values of indigenous law, which illumine continuities and discontinuities in market norms. By focussing on the context in which state law wields its ubiquitous influence on the behaviour of people who observe indigenous law, an adaptation framework presents a bottom-up approach to peacebuilding. Accordingly, I examined the relationship between state law and indigenous market laws in seven purposefully selected states in southern Nigeria. ${ }^{8}$

2 IW Zartman "Introduction: African traditional conflict 'medicine"” in IW Zartman (ed) Traditional Cures for Modern Conflicts: African Conflict "Medicine" (2000, Lynne Rienner) 7.

3 M Chanock "Neither customary nor legal: African customary law in an era of family law reform" (1989) 3 International Journal of Law and Family 72 at 76.

4 GR Woodman "Legal pluralism and the search for justice" (1996) 40/2 Journal of African Law 152.

5 JT Checkel "International norms and domestic politics: bridging the nationalist constructivist divide" (1997) 3 European Journal of International Relations 473.

6 For a similar argument on integrating state and indigenous mechanisms of peacebuilding, see R Mac Ginty "Hybrid peace: the interaction between top-down and bottom-up peace" (2010) 41/4 Security Dialogue 391.

7 For a broad argument on the adaptation of indigenous norms to socio-economic changes, see AC Diala "The concept of living customary law: a critique" (2017) 49/2 Journal of Legal Pluralism and Unofficial Law 143.

8 I selected Imo, Abia, Anambra, Enugu, Delta, Rivers and Lagos states for their ethnic, 
These seven states have an estimated population of 55 million. ${ }^{9}$ They are part of Nigeria's federal system of governance, comprising of the national government, 36 states with arguably limited economic autonomy, and close to 1,000 local/municipal councils. ${ }^{10}$ In 2017, I engaged in non-participant observation of traders and market arbitrations in Aba, Asaba, Awka, Enugu, Lagos, Onitsha, Owerri, Port-Harcourt and Warri. I supplemented these observations with archival enquiry in the National Archives, Enugu, two focus group discussions with traders and market leaders in Onitsha and Lagos, and individual interviews with 53 traders and key market informants. My research participants included traditional rulers, market union leaders, arbitrators, and village elders in rural, peri-urban, and urban communities. I probed the characteristics of indigenous market laws, their foundational values and their adaptations to socio-economic changes, notably state law. For example, in the past, trade was via waterways and exchange of agricultural products, also called the barter system. ${ }^{11}$ Later, the export trade introduced bargaining, which involved the use of cowries, brass rods and manillas. ${ }^{12}$

My investigation reveals varying discontinuities in trade systems, values and dispute resolution mechanisms. The most notable discontinuities concern indigenous trade norms. For example, market laws were motivated by communal needs, shaped by conscience and influenced by rituals. While orality of contract, absence of receipts and designated market days remain in rural areas, many aspects of market laws have disappeared in the course of traders' adaptations to socio-economic changes. These adaptations, I argue, are significant for peacebuilding discourse because they emerged from below - that is within their own socio-cultural milieu. Being bottom-up responses to socioeconomic changes, therefore, contemporary market laws possess flexible dispute resolution mechanisms with social legitimacy. Unsurprisingly, these mechanisms efficiently regulate the activities of millions of traders in Nigeria.

Following this introduction, the second part of this article examines the link between peacebuilding and interaction of normative orders in a legal system. This interaction is also referred to as legal pluralism. Starting with a brief

contd

religious and geographical homogeneity in order to assist data generalizability to the rest of southern Nigeria.

9 There is no unanimity on the population of the study area owing to the politicization of national census figures.

10 Again, there is no agreement on the number of local governments because the federal government refuses to recognize some local governments created by states. States receive money from the federal government based on their sizes, and decisions on population and number of local governments are influenced by the political party controlling the federal and state governments.

11 JN Oriji "A study of the slave and palm produce trade amongst the Ngwa-Igbo of southeastern Nigeria” (1983) 91/23 Cahiers d'Études Africaines 311.

12 Manillas were copper or brass bracelets used by the southern Igbo and Ibibio people. See WI Ofonagoro "From traditional to British currency in southern Nigeria: analysis of a currency revolution, 1880-1948" (1979) 39/3 Journal of Economic History 623 at 624. 
critique of the liberal peace model, I explain an adaptation view of legal pluralism, referring, whenever necessary, to the social settings in which indigenous market laws emerged. In so doing, I deploy the interface of state law and indigenous law as an analytical framework for the co-existence of legal systems in Nigeria. I argue that this framework should guide peacebuilding policies because state law does not have a regulatory monopoly. ${ }^{13}$ Indeed, Galanter has argued that in postcolonial societies, state law "is often a secondary rather than a primary locus of regulation". ${ }^{14}$ The article then examines the nature of pre-colonial indigenous trade. In discussing the social matrix of indigenous trade, I chart pre-colonial trade patterns, the encounter with Western influences, and adaptations to these influences. The fourth part of the article reveals contemporary market laws, showing the ways their indigenous elements have evolved in line with socio-economic changes, notably state law. These adaptations include union-based systems of market organization, statutory norms and formalized systems of dispute resolution. Unions enforce norms in both urban and rural markets in close collaboration with municipal, state and federal government authorities. ${ }^{15}$ Throughout this section, I reveal historical continuities in the foundational values that drive adaptations in indigenous market norms. I conclude by arguing that these continuities support a bottom up-approach to peacebuilding. In so doing, I highlight how the interface of state law and indigenous market laws in Nigeria could enrich policy and scholarly understanding of peacebuilding.

\section{LEGAL PLURALISM AND PEACEBUILDING}

The theoretical framework of this article exposes certain limitations of the liberal peace model of peacebuilding. In its basic formulation, the liberal peace theory posits that liberal democracies are more peaceful than other political models because their internal accountability measures deter them from warring with fellow liberal democracies. ${ }^{16}$ It traces its philosophy to classical liberals such as Adam Smith, JS Mill and Baron de Montesquieu, who asserted that trade promotes peace because conflict is antithetical to the mutual benefits of commerce. ${ }^{17}$ For liberals, "economic interdependence creates

13 SF Moore Law as Process: An Anthropological Approach (1978, Routledge) at 56.

14 M Galanter "Justice in many rooms: courts, private ordering and indigenous law" (1981) 19 Journal of Legal Pluralism and Unofficial Law 1 at 20.

15 Here, markets primarily mean marketplaces or locations of trade.

16 For criticism of the liberal peace, see R Paris "Saving liberal peacebuilding" (2010) 36/2 Review of International Studies 337; R Mac Ginty "Indigenous peace-making versus the liberal peace" (2008) 43(2) Cooperation and Conflict 139 at 139; R Fanthorpe "On the limits of liberal peace: chiefs and democratic decentralization in post-war Sierra Leone” (2005) 105 African Affairs 27.

17 A Smith An Inquiry into the Nature and Causes of the Wealth of Nations (ed SM Soares, 2007, MetaLibri Digital Library); JS Mill Principles of Political Economy (1885, Appleton and Company); C Baron de Montesquieu The Spirit of the Laws (1748, online Library of Liberty). 
incentives for co-operation, reduces misperceptions and fosters formal and informal mechanisms conducive to resolving conflicts of interest that might arise between states" ${ }^{18}$ Although the idea that commercial interdependence promotes peace is attractive, it is often illusory because it assumes symmetry in all aspects of trade. In reality, the ability of trade to induce peace is dependent on the extent to which the mutual interests of the trading partners are met. Thus, where trade is based on asymmetric ties that produce unfavourable or unequal distributive consequences, trade may cause conflict. ${ }^{19}$ Indeed, the liberal peace model fails to account for conflicts arising out of the economicdriven aggression of liberal democracies, which hides under the mantra of human rights, self-determination and the promotion of international peace and security. ${ }^{20}$ The liberal peace agendas of aid agencies and peacekeeping forces also enable multinational companies to plunder the wealth of some African countries. For example, more than 100 companies listed on the London Stock Exchange maintain mining operations in Africa with combined wealth in excess of $\$ 1$ trillion. ${ }^{21}$ Just as an economic view of liberal peace fails to account for asymmetric benefits, liberal peacebuilding fails to account for the socio-cultural complexities in the places where it is exported. ${ }^{22}$ Unsurprisingly, liberal peace interventions in many parts of Africa and Asia in the last three decades "have been largely ineffective". ${ }^{23}$ Rather than achieve durable peace, the majority of these interventions contribute significantly to unemployment, poverty, socio-political discord and even terrorism. ${ }^{24}$ In postcolonial settings therefore, there is need to approach peacebuilding from the interface of state law and indigenous law.

\section{The concept of legal pluralism}

As a concept, legal pluralism has survived passionate academic debates to become the rallying point for analysing complex legal systems. ${ }^{25}$ At the international policy level, it underpins the seemingly irrevocable shift towards

18 K Barbieri The Liberal Illusion - Does Trade Promote Peace? (2002, University of Michigan Press) at 1.

19 Ibid.

20 R Khalidi Resurrecting Empire: Western Footprints and America's Perilous Path in the Middle East (2010, Beacon Press); B Clements "Public opinion and military intervention: Afghanistan, Iraq and Libya” (2013) 84/1 The Political Quarterly 119.

21 M Curtis The New Colonialism: Britain's Scramble for Africa's Energy and Mineral Resources (2016, War on Want).

22 Mac Ginty "Hybrid peace", above at note 6 at 408.

23 C de Coning “Adaptive peacebuilding” (2018) 94/2 International Affairs 301 at 303, citing, among others, D Smith Towards a Strategic Framework for Peacebuilding: Getting Their Act Together (2004, Peace Research Institute Oslo). See also S Willett "New barbarians at the gate: losing the liberal peace in Africa" (2005) 32/106 Review of African Political Economy 569.

24 Willett "New barbarians at the gate", above at note 23.

25 F von Benda-Beckmann "Who's afraid of legal pluralism?” (2002) 34/47 Journal of Legal Pluralism and Unofficial Law 37. 
transnationalism. As de Sousa Santos noted, transnationalism is characterized by the interaction of supranational legal orders with national and subnational legal orders in a complex manner that requires a "new legal common sense". ${ }^{26}$ I utilize an adaptive view of legal pluralism founded on a processual understanding of law - that is the idea of law as a product of people's social associations rather than the product of a coercive sovereign. ${ }^{27}$ Normative ordering should not be perceived solely on the basis of state law because people's social associations encompass norms that are sometimes different from state law. These social associations resonate with indigenous law, especially in societies where indigenous law enjoyed a legal monopoly before colonial authorities superimposed their own laws. As I noted in the introduction, imposed foreign laws constitute the bulk of state law in Africa. It has been more than 100 years since these laws debuted with their accompanying economic, religious, educational and cultural changes. In this period, generations of Africans have grown up with the reality of legal pluralism. They observe indigenous law and state law in accordance with their location, cultural affiliations and socio-economic factors such as education, urbanization, independent income, acculturation and religion. Consciously or unconsciously, they trade-off both legal orders, depending on their perceived benefits. As I argue below, the nature of the social fields in which these legal orders interact compel policy attention on normative adaptations.

\section{The nature of African social fields}

Generally, human behaviour occurs in social fields, which are often semiautonomous. ${ }^{28}$ In an African context, a social field could be a place of trade, a school, farm, courtroom, health facility, motor park, traditional leader's office, municipal civic office, police station, town hall, recreation facility, a sports club, or a religious house. However, it could also be a non-physical space such as social media.

A social field often contains different normative orders, which may be state, semi-state, or non-state. Examples include indigenous law, religious norms, the constitution as well as statutory laws such as criminal laws, commercial laws, environmental laws, inheritance laws and marriage, birth and death registration laws. A non-state normative order could include motor park laws or norms regulating criminal networks. In this sense, we see that the definition and boundaries of a social field are not dictated by the state but "by a processual characteristic, the fact that it can generate rules and coerce or induce compliance to them". ${ }^{29}$ Importantly, mobility, non-isolationism and

26 B de Sousa Santos Toward a New Legal Common Sense: Law, Globalization, and Emancipation (2002, Cambridge University Press).

27 Moore Law as Process, above at note 13.

28 SF Moore "Law and social change: the semi-autonomous social field as an appropriate subject of study" (1973) 7/4 Law and Society Review 719.

29 Moore Law as Process, above at note 13 at 57. 
semi-autonomy are three key features of a social field. As I explain below, these features inform my adaptation framework of normative interaction, especially in the context of state law and indigenous trade laws.

\section{Features of a social field}

In the context of a processual meaning of law, a social field may be defined as the fundamental unit of social relations within which norms of conduct emerge, encounter external norms and adapt. The non-isolationist nature of a social field implies that its members are open to the influence of socioeconomic factors such as education, religion, urbanization, advocacy, wealth, legislation and globalization. ${ }^{30}$ In their encounter with these factors, individuals subject to indigenous law tailor their behaviour to meet the demands of contemporary modernity. By so doing, they alter indigenous laws, adopt new norms and even produce hybrid norms. ${ }^{31}$ In all these interactions in social fields, indigenous law interfaces with state law. I use Nigeria's growing trade ties with China as an example of this interface.

Usually, traders require a state licence to import goods from China. For imports, they purchase foreign currency, taking care to comply with state regulations. While in China, they could learn some aspects of Chinese culture. When their goods return to Nigeria, they are distributed to wholesalers and retailers, factoring in import duties, transport expenses and value added taxes. These goods are usually distinguished from other goods with derogatory terms and price regimes. While Chinese goods are particularly popular in periurban centres, their quality produces behavioural norms and trade values different from ancient trade values. During dispute resolution, dissonance sometimes emerges between these ancient values and new, profit-driven values acquired from external influences. Depending on the context of the dispute and the parties involved, this dissonance could result in recourse to statutory law, human rights principles and/or religious practices of swearing by sacred objects. Here, continuity with the past may be evident only in oracles, who form the bedrock of indigenous dispute resolution. ${ }^{32}$ These illustrations demonstrate the non-isolationist nature of a social field and the varied external influences that affect it.

The second feature of a social field integral to an adaptation view of legal pluralism is mobility. Just as in other African countries, most people in Nigeria belong to more than one social field. For example, many Nigerians were born in rural areas before they left for urban centres. Some reside in

30 de Sousa Santos Toward a New Legal Common Sense, above at note 26 at 94 for multisectoral influences on social fields.

31 PS Berman "Towards a jurisprudence of hybridity" (2010) 1 Utah Law Review 11; B de Sousa Santos "Law: a map of misreading. Towards a postmodern conception of law" (1987) 14 Journal of Law and Society 279.

32 Prominent oracles include the Ogwuwu Akpu of Okija, Anambra State, Ala-Ogbaga of Chokoneze in Mbaise, Imo State, Ebinokpabi/Ibini Ukpabi Oracle of Arochukwu, Abia State, and the Sango Shrine of Oyo State. 
rural areas but commute regularly to work in urban areas, while many others reside in rural areas but maintain close links with relatives in urban areas. In all these scenarios, behaviour occurs at the intersection of indigenous laws and external norms. Indeed, this is the reality for millions of traders in southern Nigeria, who regulate their lives under state law and indigenous law. By belonging to more than one normative field, these traders engage in forum shopping during disputes - choosing which legal orders to use based on their perceived benefits. For example, they could use market tribunals because of their flexible procedures, a desire to avoid high legal fees, or because of an obligation to exhaust internal market remedies. They may also settle their disputes in regular courts or religious bodies using principles of state law or religious norms, both of which may lie outside their social field of indigenous laws.

Significantly, Africans are long used to multi-dimensional social fields. As Gugler observed in the seventies, most Africans have one foot in cities and the other foot in villages. ${ }^{33}$ This mobility involves reliance on indigenous law and state law. Interestingly, urban market tribunals were originally modelled on indigenous dispute mechanisms before they came under the influence of state law. In response to changed social settings and values, however, urban tribunals increasingly resort to market constitutions and byelaws modelled on state law. In this sense of mobile social fields, the interaction of laws demands an adaptation approach.

The last feature of a social field is semi-autonomy. A social field is semiautonomous because its members possess varying abilities to resist the penetration of external norms. ${ }^{34}$ Usually, their reception of external norms involves the exercise of agency within diverse socio-economic factors such as education, wealth, religion, unemployment, urbanization and state law. Some examples of normative semi-autonomy are traders' compliance with high tariffs, resistance to government interference in market organization, or defiance of market laws prohibiting resort to the courts without exhausting the remedies of market tribunals.

In the context of state law's interface with market laws, the perceived benefits of a normative order influence traders' exercise of agency. These benefits include shop rental rates, import duties, taxation and sanitation laws. People's exercise of agency arguably produces behavioural adaptations. As I show below, an adaptive view of legal pluralism is valuable for understanding how the interface of state law and indigenous law contributes to peacebuilding.

33 J Gugler "Life in a dual system: eastern Nigerians in town, 1961" (1971) 11/43 Cahiers d'Études Africaines 400 at 401.

34 AC Diala "Legal pluralism and social change: insights from matrimonial property rights in Nigeria" in C Rautenbach (ed) In the Shade of an African Baobab: Tom Bennett's Legacy (2018, JUTA) 155; Moore "Law and social change", above at note 28. 


\section{Holistic peacebuilding}

First, the interrelatedness of law, human security and peace is no longer in doubt. ${ }^{35}$ Following the persistence of major conflicts after the Second World War, policymakers realized the need to reconceptualize peacebuilding as a comprehensive process involving the promotion of harmonious social relationships based on human dignity. ${ }^{36}$ This holistic view of peace recognizes the interdependence and interrelatedness of human rights, as well as the inseparability of these rights from social activities that produce injustice. ${ }^{37}$ As Jacobs noted, peacebuilding "can only be achieved by a comprehensive, integrated approach that addresses the roots of violence and disharmony in all forms - political, military, economic, social, cultural and ecological [to ensure] the essential condition for the fullest development of human potential" ${ }^{38}$ In this sense, peacebuilding policies that are sensitive to the interface of state law and indigenous trade laws would reveal better the socio-cultural nuances that induce, influence and sustain conflicts.

Second, legal pluralism involves social, economic, cultural and religious elements that inform human security and, thereby, affect the success of peacebuilding. ${ }^{39}$ As "a central theme" in law's relationship with society, ${ }^{40}$ legal pluralism is problematic in postcolonial states that inadequately acknowledge non-state normative orders such as indigenous law. ${ }^{41}$ The problems of legal pluralism include conflict of laws, the dissonance between indigenous laws and changed social conditions, judicial recognition of indigenous law without its foundational values, and application of an individualistic human rights regime to norms that emerged in close-knit, communalistic settings that favoured group interests. Suffice it to say that inadequate acknowledgment of indigenous law manifests in a neglect of the socio-economic factors that inform human security.

Finally, the manner legal transplant occurred in Nigeria encourages conflicts. Although colonial officials acknowledged indigenous legal orders, they used Western viewpoints to impose varying degrees of restrictions. Regrettably, these restrictions often ignore the foundational values of

35 C Ukeje "Globalization and conflict management: reflections on the security challenges facing West Africa” (2008) 5/1 Globalizations 35; OP Richmond "Emancipatory forms of human security and liberal peacebuilding” (2007) 62(3) International Journal 459; E Conteh-Morgan "Peacebuilding and human security: a constructivist perspective" (2005) 10/1 International Journal of Peace Studies 69.

36 JG Cockell "Conceptualising peacebuilding: human security and sustainable peace" in M Pugh (ed) Regeneration of War-Torn Societies (2000, Palgrave Macmillan) 15.

37 Vienna Declaration and Programme of Action, adopted by the UN General Assembly, UN doc A/CONF.157/23 (12 July 1993).

38 G Jacobs "Integrated approach to peace and human security in the 21st century" (2016) 3/1 Cadmus 48.

39 Conteh-Morgan "Peacebuilding and human security", above at note 35

40 SE Merry "Legal pluralism" (1988) 22 Law and Society Review 869 at 869.

41 C Rautenbach "Deep legal pluralism in South Africa: judicial accommodation of nonstate law" (2010) 42/60 Journal of Legal Pluralism and Unofficial Law 143. 
indigenous law, which emerged in response to the close-knit, communal settings in which people lived. ${ }^{42}$ When these values are isolated from indigenous law, hardships occur. Arguably, therefore, peacebuilding struggles if policies pay insufficient attention to people's adaptation of indigenous laws to modern conditions. In this context, I provide below an account of trade in the precolonial era to chart how Nigeria's encounter with foreign cultures altered indigenous market laws.

\section{THE NATURE OF INDIGENOUS TRADE LAWS}

When I started studying indigenous trade laws in southern Nigeria, I was immediately confronted with a serious shortage of published research on this subject. ${ }^{43}$ However, this distressing gap in knowledge is not unique to Nigeria. While literature abounds on state laws of contract in sub-Saharan Africa, relatively nothing exists on indigenous trade laws. ${ }^{44}$ When I eventually took to the field in January 2017, I was shocked at the failure of many of my interviewees to describe indigenous trade laws. I was compelled to obtain my data from mostly elderly men, who, in many instances, gave information they acquired from their parents and from oral traditions passed down through the generations. From these sources and bits of archival information, I wove a picture of indigenous market laws in the last two centuries. Before I describe these norms, I will use their socio-political matrix to set a background for understanding continuities and discontinuities in contemporary market laws.

\section{Social matrix of pre-colonial trade}

In this article, the pre-colonial era is the period before 1900, which is the year Britain revoked the charter of the Royal Niger Company, its pseudo-political corporate behemoth in West Africa. This revocation effectively brought all

42 To safeguard family interests, indigenous law restricts land alienation and requires heirs to promote the best interests of deceased persons' dependants. For analysis, see AC Diala and B Kangwa "Rethinking the interface between customary law and constitutionalism in sub-Saharan Africa" (2019) 52 De Jure 194; AC Diala "Reform of the customary law of inheritance in Nigeria: lessons from South Africa" (2014) 14/2 African Human Rights Law Journal 633.

43 There is, however, modest research on pre-colonial trade. See, eg, UI Ukwu "The development of trade and marketing in Iboland" (1964) 3/4 Journal of the Historical Society of Nigeria 649; KO Dike Trade and Politics in the Niger Delta, 1830-I885: An Introduction to the Economic and Political History of Nigeria (1956, Clarendon Press); GI Jones The Trading States of the Oil Rivers (1963, Oxford University Press); EJ Alagoa The Small Brave City-State: A History of Nembe-Brass in the Niger Delta (1964, Ibadan University Press); CM Good "Markets in Africa: a review of research themes and the question of market origins" (1973) Cahiers d'Études Africaines 769 at 769; GI Jones "Native and trade currencies in southern Nigeria during the eighteenth and nineteenth centuries" (1958) 28/1 Africa: Journal of the International African Institute 43.

44 GJ van Niekerk "Orality in African customary and Roman law of contract: a comparative perspective” (2011) 44/2 De Jure 364. 
southern Nigerian communities under British political authority. These communities, stretching from Lagos and the old Oyo Empire to the Niger Delta and Igbo hinterlands, became known as the Southern Nigeria Protectorate. In 1914, it united with the Northern Nigeria Protectorate (Kano, Sokoto, and Bornu kingdoms) to form the Colony and Protectorate of Nigeria. In reality, however, the foundations for British control of Nigeria were laid in the 18th century through trade-motivated explorations. ${ }^{45}$ To fully comprehend the nature of the indigenous trade that preceded British control, it is necessary to explain trade patterns in Southern Nigeria.

\section{Pre-colonial trade patterns}

The year when Nigerian communities started trading among themselves is unknown. However, the literature suggests that some riverine communities in southern Nigeria had been trading with the Portuguese as far back as the 15th century. ${ }^{46}$ Not much is known of this trade since the literature mostly starts from the 18th century, or centres on the 19th and 20th centuries. However, oral legends and archaeological findings in southern Nigeria indicate the nature of trade in ancient times. For example, at Igbo-Ukwu in Anambra State, archaeological artefacts, which were carbon-dated to the $9^{\text {th }}$ century $\mathrm{AD}$, show evidence of advanced copper and bronze work techniques, iron draw-plates, beads, woven clothes and pottery of unusual skill. ${ }^{47}$ Some of these artefacts seem to have come from Venice and India, ${ }^{48}$ suggesting the existence of advanced international trade in ancient times. The artefacts support information from some Anambra informants about an ancient Nri dynastic hegemony over large parts of southern Nigeria. ${ }^{49}$ These oral legends hold that earthly civilization began in Nri when Eri, a 'sky being' and royal founder of the Nri Kingdom, landed on earth and established a civilization. ${ }^{50}$ In any case, the Igbo Ukwu artefacts question data from other parts of south-east Nigeria, which involve trade practices more suited to agrarian political economies than economies that conducted international trade. Two scenarios may resolve this discrepancy.

In scenario one, my interviewees could have obtained their accounts of indigenous trade from family members with limited information. For example, the accounts of trade by some traditional leaders in Enugu and Imo are

45 JC Anene "The foundation of British rule in 'southern Nigeria' (1885-1891)" (1959) 1/4 Journal of the Historical Society of Nigeria 253.

46 AFC Ryder Benin and the Europeans: 1485-1897 (1969, Humanities Press).

47 CT Shaw Igbo-Ukwu: An Account of Archaeological Discoveries in Eastern Nigeria (1970, Faber and Faber). But see T Shaw "Those Igbo-Ukwu radiocarbon dates: facts, fictions and probabilities" (1975) 16/4 Journal of African History 503.

48 Shaw Igbo-Ukwu, above at 47 at 225-239.

49 For an explanation of this dynasty, see MA Onwuejeogwu Nri Kingdom and Hegemony: An Outline of Igbo Civilisation, AD 994 to Present (1980, Tabansi Press). See also MD Jeffreys "The divine Umundri king" (1935) 8/3 Africa 346 at 350-52, 354.

50 See, eg, MD Jeffreys "The Umundri tradition of origin" (1956) 15/3 African Studies 119. 
sophisticated because they were privy to information that other interviewees lacked. ${ }^{51}$ In any case, the Igbo-Ukwu artefacts show "evidence of a centralized authority" in ancient southern Nigerian communities. ${ }^{52}$

In scenario two, the sophisticated Nri society suggested by legends and archaeological findings may have been replaced at some point by a subsistence-agriculture society. Historically, civilizations tend to disappear or diminish through wars and natural disasters. Indeed, one legend posits that a catastrophic flood, allegedly a divine intervention in a dispute between Eri's descendants, ended the first civilization he established and created the Anambra (Omambala) River. In any case, many Igbos believe they never migrated from anywhere outside their homeland, thus indirectly laying claim to pre-historic origins. ${ }^{53}$

Unfortunately, the Igbo-Ukwu artefacts provide unreliable information on the nature of trade norms in ancient times. In the light of scant data on ancient Nigerian societies, the lack of unanimity in available information, and the reality of cultural pluralism, I can only describe general principles of indigenous market laws. What follows is an attempt to reconcile these principles with literature on pre-colonial trade patterns.

\section{Pre-colonial trade patterns}

By 1900 when Britain formally assumed control of Nigeria, advanced "networks of trade" had already been established in southern Nigeria through waterways. ${ }^{54}$ Indeed, control of the waterways practically amounted to control of economic, political and military power. ${ }^{55}$ Trade networks comprised of several communities that co-operated on largely salt and palm oil commerce in or near Lagos, the Niger River and major inland markets. ${ }^{56}$ Many of these markets were in Awka, Onitsha, Oguta, Calabar (Kalabari), Bonny Island and the Benin Kingdom. Others were trade posts and fairs controlled by the war-like

51 These accounts were provided by the traditional leaders of Isu-Awaa in Awgu, Enugu, Umuaghara Onicha Nwenkwo in Ezinihitte Mbaise, and Alaoma Owerri-Ebeiri in Orlu, Imo State.

52 CT Shaw "The significance of Igbo-Ukwu and future archaeological research in southeastern Nigeria" (1972) 1/1 Ikenga: Journal of African Studies 3.

53 A notable historian quoted an Mbaise elder thus: "The Igbos did not come from anywhere and the ancestors of the Igbo people originated from where they live today starting from Nri, an ancient clan in present Anambra State." See EA Isichei A History of the Igbo People (1976, Palgrave Macmillan); CO Acholonu They Lived before Adam: Pre-historic Origins of the Igbo - The Never-Been-Ruled (Ndi Igbo since 1.6 Million BC) (2009, Fylann Limited).

54 D Northrup "The growth of trade among the Igbo before 1880" (1972) 13/2 Journal of African History 217 at 217.

55 Dike Trade and Politics in the Niger Delta, above at note 43 at 62.

56 CWS Hartley The Oil Palm: Elaeis Guineesis Jacq (1967, Longmans) at 1-9; HW Gilmore “Cultural diffusion via salt” (1955) 57/5 American Anthropologist 1011. 
traders of Arochukwu, their allies and their vassal communities of Abam and Ada. ${ }^{57}$

Northrup attempted to chart pre-colonial trade patterns "by extrapolating back from the patterns of trade described by European explorers in the second quarter of the nineteenth century". ${ }^{58}$ According to him, the Igala Kingdom and communities in or near the Delta dominated trade in the Niger-Benue confluence in the early nineteenth century.59 In 1841, Laird and Oldfield reported that traders met at "the Eggarah market [near Asaba] directly after the new moon", a journey of about five days, where "they receive the produce of the interior, brought there by the Eggarah [Igala] people"' which they "exchange at the lower market with the traders from Brass and Bonny". ${ }^{60}$ Citing multiple historians and anthropologists such as Isichei, Allen, Thompson, Laird and Oldfield, Northrup stated: ${ }^{61}$

\begin{abstract}
"The market ... was held on a sandbar, or in canoes when the water was high ... Igala Bank market was near the town of Asaba (opposite Onitsha) and was the centre of a complex of riverine and overland trade routes. To Asaba came traders from as far west as Benin; the Igbo on the east bank sent their products through Aboh, Onitsha, and other towns. From the south, Delta products and European goods came upstream in the hands of Aboh traders, and the Ogala traders of Idah and Adamugu brought downstream the produce and horses of the Igala hinterland. ... The volume of the trade at Igala Bank is difficult to estimate with any accuracy, and no doubt it fluctuated with the seasons and with the years. Yet, it appears to have been considerable. In the early 1830s, some 300 canoes were seen going up to the market and in 1841 , sixty canoes, holding from two to 70 men were observed returning from it."
\end{abstract}

The market at Idah was largely an exchange (barter) market. It "met every ten days for up to three days at a time, drawing traders from as...far north as the kingdom of Nupe on the Niger and the Igbira metropolis of Punda, a weaving and smithing centre of 30,000 inhabitants north of the Benue". ${ }^{62}$ This market was larger than the Igala Bank market since it took advantage of the

57 RO Igwegbe The Original History of Arondizuogu from 1635-1960 (1962, International Press); WRG Horton "The Ohu system of slavery in a northern Ibo village-group" (1954) 24/4 Africa: Journal of the International African Institute 311.

58 Northrup "The growth of trade", above at note 54 at 221

59 Ibid.

60 M Laird and RAK Oldfield Narrative of an Expedition into the Interior of Africa: By the River Niger, in the Steam-vessels Quorra and Alburkah, in 1832, 1833 and 1834 (1837, Richard Bentley) at 102.

61 Northrup "The growth of trade", above at note 54 at 222, citing Laird and Oldfield Narrative of an Expedition; TTR Heywood A Narrative of the Expedition Sent by Her Majesty's Government to the River Niger in 1841 under the Command of Captain HD Trotter (1848, Frank Cass) at 270; E Isichei "Historical change in an Ibo polity: Asaba to 1885" (1969) 10/3 Journal of African History 421.

62 Northrup "The growth of trade", above at note 54 at 222. 
confluence of two great rivers and several overland routes. In 1832, European explorers observed Muslim traders "selling Nupe mats, straw hats, ivory, long robes, Indian corn, rice, flour, small horses, slaves, locally made blue beads, beer, coconuts, sheep, goats and dogs". ${ }^{63}$ Explorers also observed the use of cowries in trading involving crowds of up to 6,000, as well as an estimated annual sale of some 11,000 slaves. ${ }^{64}$ Lagos was the centre of commerce in South-West Nigeria, while notable trading colonies in south-east Nigeria included Azumini, Awka, Asaba, Akwete, Arochukwu, Eleme, Elele, Ndoni, Ohambele, Onitsha, Omoku, Oguta, Obigbo, Owerrinta, Urantta and Usemodu. ${ }^{65}$ From the hinterlands of present-day Abia State, Aro traders travelled to coastline communities of Calabar, Bonny and Opobo to sell their goods to middlemen, along with traders operating near the Ikwere, Etche and Ngwa territories. ${ }^{66}$

However, anthropological literature on this pre-colonial trade offers no account of market laws. This omission is understandable, given that most of the literature was written by historians not legal anthropologists. Moreover, early colonial officials were not interested in documenting indigenous laws because their primary motivation was economic. In offering an account of indigenous trade laws, therefore, I focus on trade values rather than norms. I use, primarily, oral accounts, and secondarily, snippets of information in archives and my deductions from anthropological literature on pre-colonial social life in southern Nigeria.

\section{Character of indigenous trade laws}

In the past, inter-tribal trade often involved the use of sign language. This indicates considerable trust. In the words of informants, "indigenous trade laws were derived from the gods and operated on conscience", which is symbolized in this maxim, "behave with others as you will like them to behave with you". ${ }^{67}$ The overall principle of commerce was fairness. My informants referred to fairness with various terms such as justice, uprightness and conscience. These terms are of course approximations of the indigenous expressions of fairness. For example, fairness arguably means $i k w u$ aka oto in Igbo and didara in Yoruba. As the foundational value of trade, fairness is well-suited for exchange markets (barter), a system driven by the needs of the family and kin. In explaining fairness, an informant stated: "it is difficult to cheat when

\footnotetext{
63 Ibid.

64 Laird and Oldfield, Narrative of an Expedition, above at note 60; SA Crowther Journal of an Expedition up the Niger and Tshadda Rivers: Undertaken by Maegregor Laird in Connection with the British Government in 1854 (1855, Church Missionary Society) at 171-73.

65 Dike Trade and Politics in the Niger Delta, above at note 43.

66 Ukwu "The development of trade and marketing", above at note 43 at 655.

67 Interviews with Steven Edeokoye of Idumota Market, Lagos, 31 January and 3 February 2017, Pa Cyril Elegalam of Umumgbeke Village, Ugirike, Imo State, 8 February 2017, and His Royal Highness, Igwe (Dr) Udemgaba Maduka (JP), the Iyiakwa 1 and Okaibe 11 of Isu-Awaa, and Akazuoha 1 of Enugu, 10 February 2017.
} 
you are simply exchanging goods with someone who knows their worth". ${ }^{68}$ In close-knit, subsistence-agriculture communities, needs were easily satisfied through an exchange of food crops and items such as ivory, salt, cotton and tobacco. Although these products constituted wealth, the indigenous understanding of wealth included humans. ${ }^{69}$ In the words of an octogenarian, "the measure of wealth was a man's wives, children and yam barns". ${ }^{70}$ Merchants bought goods from local markets and sold to middlemen for export, a practice with historical continuity in rural markets, which feed export-oriented, large markets in urban areas.

Furthermore, trade occurred on designated market days and within stipulated periods, while market laws prohibited trade during religious festivals or sacred days. ${ }^{71}$ Indeed, many communities named markets after gods and goddesses, even though some markets trace their nicknames elsewhere. ${ }^{72}$ However, exceptions were sometimes made for early morning and evening daily markets, which focussed on perishable products such as fish and vegetables. ${ }^{73}$ Periodicity enabled people to rest from farm work, pursue crafts and celebrate sacred festivals. Thus, it reveals the sacred functions of markets and their close connection with religious laws. ${ }^{74}$ These functions are now largely defunct, although periodicity remains in rural markets. ${ }^{75}$

Although market organization was generally informal, trading was very formal in coastal communities, which, as explained, had developed fairly centralized governance long before the British arrived in Nigeria. ${ }^{76}$ In these communities, market laws were clearly defined and enforced by religious and traditional authorities such as the Omu, a female pseudo-monarch in Asagba (Asaba). ${ }^{77}$ The formality of laws continues in the constitutions of market unions.

Prior to the introduction of cowries and brass money, stones and special sticks represented value in parts of south-east Nigeria. For example, some communities in Imo State used sticks extracted from palm trees (okporo ngwo) as

68 Interview with Eze-elect Bakason Boniface Ohanaga of Umuaghara, Onicha Nwenkwo autonomous community of Ezinihitte Mbaise, Imo State, 17 February 2017.

69 N Uka Growing up in Nigerian Culture (1966, Ibadan University Press).

70 Interview, Pa Cyril Elegalam, 8 February 2017.

71 BW Hodder and UI Ukwu Markets in West Africa: Studies of Markets and Trade among the Yoruba and Ibo (1969, Ibadan University Press).

72 MDW Jeffreys "The Umundri traditions of origin" (1956) 15/3 African Studies 125.

73 Ukwu "The development of trade and marketing", above at note 43 at 650 . These daily markets are called Ogwumabiri/Ogwunabiri in Igbo and oja aaro/ale in Yoruba.

74 See generally Hodder and Ukwu Markets in West Africa, above at note 71.

75 TH Eighmy "Rural periodic markets and the extension of an urban system: a western Nigeria example” (1972) 48/3 Economic Geography 299; MC Onukawa "An anthropolinguistic study of Igbo market-day anthroponyms” (1998) 11/1 Journal of African Cultural Studies 73.

76 EA Isichei A History of the Igbo People, above at note 53 at 49-63.

77 K Okonjo "The dual-sex political system in operation: Igbo women and community politics in midwestern Nigeria" in N Hafkin and E Bay (eds) Women in Africa: Studies in Social and Economic Change (1976, Stanford University Press) 47. 
measures of value. It is unclear if this system of measurement is the same one Meek described as umumu currency. ${ }^{78}$ Umumu would seem to be different, since it performed symbolic roles in sacrifices, purification ceremonies and land transactions, and was nowhere worth its value in size. ${ }^{79}$

Pre-colonial commerce did not require evidence because "people's words (promises and assurances) were trusted" and "honour and integrity were high". ${ }^{80}$ As a foundational value of indigenous trade laws, trust reflected the fact that traders lived close by, could be traced easily, and therefore were not disposed to fraud. Accordingly, trade involved neither receipts nor written agreements. Eventually, however, trust began to be sealed with personal covenants in transactions involving land. ${ }^{81}$ Covenants marked the special spiritual connotations of land in southern Nigeria and involved ritual items such as kola nuts, salt and water. ${ }^{82}$ Later, the trust-based system of indigenous trade started eroding with the replacement of exchange trade with currencies (initially cowries) and bargaining. Monetization, along with other socio-economic changes such as urbanization, profit-seeking and individualistic worldviews, resulted in the use of receipts in commercial transactions.

Significantly for legal pluralism, there was a limited choice of law in the precolonial era because indigenous law enjoyed a legal monopoly. A possible exception for choice of law was variations of norms across communities. In this context, trade disputes were comparatively easy to adjudicate by the kinsmen or elders, with appeals to oracles in serious cases. ${ }^{83}$ As pointed out, fraud was rare, and the few offenders were punished severely through fines combined with open apology and disgrace such as being paraded naked in the marketplace.

From the picture informants painted of indigenous trade laws, I distilled some common elements relevant to peacebuilding. These are humanness or fairness, trust, reconciliatory dispute resolution, performance-based liability and primacy of communal needs. ${ }^{84}$ Some of these elements have since changed in response to Nigeria's encounter with other cultures. It would be too simplistic to describe these changes without providing a glimpse of their historical milieu. Accordingly, I offer, below, an abridged, trade-related account

78 CK Meek Law and Authority in a Nigeria Tribe: A Study of Indirect Rule (1937, Oxford University Press) at 452.

79 Id at 104; GT Basden Niger Ibos (1938, Seeley, Service \& Co; 1966, Frank Cass) at 339-340.

80 Interview with His Royal Highness Eze Anselm K. Okorie Ikegwoha (JP), traditional ruler of Alaoma Owerri-Ebeiri Autonomous Community, Orlu, 11 February 2017.

81 Personal covenants are referred to as igbandu or oriko in Igbo and majemu in Yoruba.

82 P Talbot The Peoples of Southern Nigeria Vol. 3 (1937, Frank Cass) at 682.

83 GI Jones The Trading States of the Oil Rivers (1963, Oxford University Press) at 70, 87; AG Leonard "Notes of a journey to Bende" (1898) 14 Journal of the Manchester Geographical Society 190 at 191.

84 Some of these elements find support in literature. See, eg, J Mbiti African Religions and Philosophy (1970, Heinemann); G Ayittey Indigenous African Institutions (2006, Brill Publishers) at 91. 
of British control of Nigeria, which will set the stage for my discussion of contemporary market laws in southern Nigeria and their interface with state law.

\title{
Colonial control of Nigeria
}

The colonial control of Nigeria was ostensibly driven by missionary activity and anti-slave trade campaigns. Britain had outlawed the slave trade in 1833 and embraced "legitimate commerce" in agricultural and oil products. ${ }^{85}$ Legitimate commerce essentially consisted of the British taking ivory, cotton, peanuts, palm oil, and later, diamonds, gold, emeralds, copper and coal from Africans, in exchange for mirrors, gunpowder and "six-foot guns that took up to a minute to reload." 86 This type of asymmetric trade is unsuited to peacebuilding. As summarized in the below extract, it mirrored the deception and force the British employed in other African countries: ${ }^{87}$

\begin{abstract}
"Some Africans resisted the takeover, but the Europeans, no slouches at savage violence, most often swept their spear-wielding armies aside with the Maxim gun and repeater rifle, and brutally crushed local resistance. Much of Africa gave in without a fight, its kings signing away their sovereignty with a thumbprint. Many allied with the intruders, maybe believing that these would not stay long and would give help against some local rival. Some tried to play one set of Europeans off against another. Others were overawed by technology: the kingdoms of northern Nigeria surrendered to forces led by a handful of white men far smaller than their own."
\end{abstract}

It is unclear what sort of indigenous laws governed trade between Nigerians and the British in the lower Niger and coastlines of Lagos. If the indigenous laws involved in this trade possess the features of the norms I have described, then they explain British success in exploitative trade. In any case, mosquitoborne malaria repelled early explorers from the hinterlands of southern Nigeria. ${ }^{88}$ The British turned to northern Nigeria, delighted with the aristocratic society and organized religion in the kingdoms of Bornu, Kano, and the Sokoto Caliphate.

\section{Penetration of hinterland markets}

British fortune turned with the discovery of quinine in the 1850s. Armed with this medicine, they began expanding their reach deep into the hinterlands of

85 PS Caulker "Legitimate commerce and statecraft: a study of the hinterland adjacent to nineteenth-century Sierra Leone" (1981) 11/4 Journal of Black Studies 397.

86 RB Edgerton The Fall of the Asante Empire: The Hundred-Year War for Africa's Gold Coast (2010, Simon and Schuster).

87 "The scramble for Africa" (23 December 1999) The Economist, available at: <https://www. economist.com/node/347120> (last accessed 22 May 2018).

88 Crowther Journal of an Expedition, above at note 64 at xxviii. 
southern Nigeria. ${ }^{89}$ They set up trade policies, consolidated trade outposts and fuelled divisions among tribes. For example, European weapons altered the dynamics of trade in the Niger Delta, enabling communities to subdue territories and morph into city states. ${ }^{90}$ These states were built around the heads of their most dominant trading firms, which were called Houses. Driven by new values of greed, Houses fought for trade and political control. For instance, Jubo Jubogha, better known as Jaja of Opobo, established dominance as the head of the Anna Pepple House. ${ }^{91}$

In 1885, Britain declared a "protectorate" over the Niger Delta territories, thereby expanding its control from Lagos to communities on both banks of the Niger River. In 1886, it granted a licence to the National African Company (later Royal Niger Company) to administer trade in its protectorates. ${ }^{92}$ Working closely with British troops, this company marginalized coastal communities from their long-established waterways trade, punished stubborn tribal authorities and imposed licences, tax and import duties on merchandise. ${ }^{93}$ As I show, this coercive model of trade control resonates strongly with contemporary state regulation of markets. Gradually, "the centre of gravity of [indigenous] trade shifted from the coastal ports to the creek and river stations now controlled by the [Royal Niger] Company". ${ }^{94}$

\section{Changes to indigenous trade}

Since trade is part of social life, it was inevitable for coercive colonial rule to change indigenous trade laws. Notable changes include an emphasis on export crop production, displacement of the indigenous land tenure system and a focus on individualistic, profit-driven values. ${ }^{95}$ Other changes reflect a craving for imported merchandise, the rise of road networks and railways and the construction of bridges to suck in palm produce from the hinterland. Roads and railways accelerated urbanization and attracted trading communities, which "formed the nucleus of new commercial towns". ${ }^{96}$ Urbanization was accompanied by the rise of European-styled factories operating as

89 SN Nwabara "British foundation of Nigeria: a saga of hardship, 1788-1914" (1963) 13/3 Civilisations 308 at 312.

90 CD Forde and GI Jones The Ibo and Ibibio-Speaking Peoples of South-Eastern Nigeria (1967, OUP-International African Institute).

91 Jaja successfully battled the Manilla Pepple House, taxed British traders and exported oil directly to Liverpool. See SJS Cookey King Jaja of the Niger Delta: His Life and Times, 18211891 (2005, University of Granada Publishing).

92 JC Anene Southern Nigeria in Transition 1885-1906: Theory and Practice in a Colonial Protectorate (Cambridge University Press, 1966).

93 H Galway "The rising of the brassmen" (1935) 34/135 Journal of the Royal African Society 144.

94 Ukwu "The development of trade and marketing", above at note 43 at 657.

95 CK Meek "A note on crown land in the colonies" (1946) 3/28 Journal of Comparative Legislation and International Law 87.

96 Ukwu "The development of trade and marketing", above at note 43 at 660. 
permanent markets, contrary to the periodicity of indigenous markets. ${ }^{97}$ With the lure of frequent trading, shiny new products from Europe and proximity to colonial outposts, new market values quickly displaced indigenous values. ${ }^{98}$

The impact of colonial administration on indigenous trade laws are significant, since the same places that served as operating bases for conquering southern Nigeria "eventually became headquarters of administrative districts". ${ }^{99}$ Given the revolutionary changes caused to social life by colonial rule, it would have been miraculous for indigenous trade laws to retain their pre-colonial identity. I have pointed out that state law, along with its accompanying socio-economic culture, is a masquerade for transplanted European laws. In what follows, I reveal the extent to which state law affects contemporary market laws in southern Nigeria.

\section{CONTEMPORARY MARKET LAWS}

Markets in southern Nigeria encompass traditional markets in rural areas and modern markets in urban areas. However, the line between traditional markets and urban markets is increasingly blurred owing to industrialization. Industrialization means that in both villages and urban areas, street markets abound. ${ }^{100}$ These street markets often operate without any written rules except state-imposed environmental and public safety laws. Given the contextual difficulty of describing the norms used in street markets, my description of market laws primarily concerns formal markets, which I visited in and near Aba, Asaba, Awka, Enugu, Lagos, Nnewi, Owerri, Port Harcourt and Warri. I offer this description within my discussion of market organization.

\section{Market unions}

Markets are usually organized under unions. A market union is a body that oversees the daily organization of markets, resolves disputes affecting traders and acts as a pressure group for promoting the interests of its members. Unions are not restricted to urban markets, since some markets in rural areas also have unions, even though they may lack codified laws. Many unions, especially in large, commercial cities, are registered as a body corporate under

97 BW Hodder "Rural periodic day markets in part of Yorubaland" (1961) 29 Transactions and Papers (Institute of British Geographers) 149.

98 SC Ottenberg and P Ottenberg "Afikpo markets: 1900-1960" in PJ Bohanan and G Dalton (eds) Markets in Africa (1962, North-Western University Press) 196.

99 Ukwu "The development of trade and marketing", above at note 43 at 659. Examples of administrative sites are Enugwu, Owerre, Bende, Awka, Okigwi, Aba, Afikpo, Abakaliki, Udi and Orlu. Indeed, the attempts of colonial authorities to eradicate indigenous tribunals contributed to the distortion of indigenous trade laws. See, eg, JC Messenger "The role of proverbs in a Nigerian judicial system" (1959) 15/1 Southwestern Journal of Anthropology 64.

100 Street markets are called Oja gbamgba in Yoruba. See generally BW Hodder "Distribution of markets in Yorubaland" (1965) 81/1 Scottish Geographical Magazine 48. 
Part C of the Nigerian Company and Allied Matters Act, a colonial heritage. Registration gives unions power to sue and be sued.

A union may have sub-unions. For example, the Ogbete Main Market Traders' Association (OMMTA) of Enugu State is the umbrella union for all traders in Ogbete Market and its associated motor parks. Like most large unions, it is composed of sub-zones called "commodity zones" and "commodity lines."101 A zone is a branch of a market union that specializes in specific type(s) of products, while a line is a subset of a zone. For example, a zone could be composed of all sellers of building materials. So, in a zone of building material sellers, a line could be made up of sellers of cement, while other lines could specialize in paint, roofing sheets and key locks.

Varying fees apply to the membership of unions. ${ }^{102}$ As a sub-union, lines may be required to register within or through a zone. For example, section 4 of the Owerri Main Market Amalgamated Traders' Association (OMMATA) of Imo State stipulates: "Membership to OMMATA shall be through lines, while new lines shall register with OMMATA with the sum of $\$ 2000 . "$

A union has an executive committee, although the composition varies. There may also be sub-committees or "departments" on peace, welfare, environment, security, fire/electricity and safety. ${ }^{103}$ The number of committees depends on the size of a market and level of government control. However, this does not mean that all large markets have multiple layers of union organization. Generally, a central executive committee may include a president, vice-president, secretary, assistant secretary, financial secretary/treasurer, publicity secretary or public relations officer, enforcer, messenger/circular bearer, trustee, patrons, legal adviser and appointive officers. Appointive officers may include the chairperson and secretary of commodity zones and lines.

A union may form part of a central body of traders in a local government, which, in turn, forms part of the umbrella body of traders in a state. For example, the Success Market Union in Idumota, Lagos is under the Ikeja Market Union, headed by the "iyaloja-general of Nigeria," Chief (Mrs) Folashade Tinubu-Ojo. The iyaloja-general is the titular head of all markets in Lagos, even though her title gives the impression that she is the head of all Nigerian markets. ${ }^{104}$ Her male equivalent is the babaloja, while other traditional Yoruba market leaders are referred to as iyalate, iyalaje and iyalode. These titles reflect continuity in indigenous market organization, which

101 Art 5 of the amended OMMTA Constitution.

102 For example, the OMMTA Constitution states its membership fee to be 1,000 .

103 Interviews with Obute Aloysius, chairman of the Ogbete Market Peace and Disciplinary Committee, 2 February 2017, and Olori Olabisi Falodun-Onagoruwa, the iya oja (market general) of Union Homes Shopping Complex (Success Market Union) Idumota, Lagos, 27 February 2017.

104 OB Olaoba and OE Ojo "Influence of British economic activities on Lagos traditional markets, 1900-1960” (2014) 23 Journal of the Historical Society of Nigeria 111. 
linked markets to traditional authority. The relative peace in Lagos markets is traceable to the cultural legitimacy attached to traditional authority. ${ }^{105}$

Market unions claim to be independent, even though they operate under the umbrella of state law. For example, traders either pay tax to a local government or pay rents for shops built by the government. Indeed, where rentals and market locations are ill-managed, conflicts may arise. ${ }^{106}$ As many union officials disclosed, appeals from market tribunals go to state courts, who recognize these tribunals as quasi-judicial bodies. Generally, government regulation of unions covers issues of sanitation, property, environment, security, religion and finance. The inter-connectedness of these issues implies a symbiotic relationship between state officials and union leaders. For example, state governors routinely woo union leaders during elections, and, in turn, provide them with cars, office equipment and security/communication tools. Indeed, police authorities permit market vigilantes to carry weapons, enforce curfews, conduct stop and search operations and make arrests. In volatile regions like Warri, police and military personnel oversee market security. A full exploration of government influence on market organization cannot fit within the confines of this article. It suffices to point out this influence through market laws.

\section{Market laws}

In varying degrees, market laws retain traces of their pre-colonial spirit of fairness. This is evident in union constitutions, which include phrases such as "justice to all", "love, peace and unity" and "welfare and progress". I managed to access the constitutions of markets in Awka, Enugu, Lagos, Onitsha, Owerri and Warri. These documents stipulate the "dos and don'ts" of trade, as well as market organization. Many of them are supplemented with "bye-laws" containing rules of daily conduct. ${ }^{107}$ These rules range from prohibition of theft, fighting, smoking, poaching and harassment of customers, to fines against illegal parking, dumping of waste, and even storage of large sums of cash in shops. Here, the influence of state law is most evident in traders' attempts to conform market laws to government regulations. It is also evident in their use of lawyers in the formulation of market laws. ${ }^{108}$ Unsurprisingly, there is increasing legal terminologies in market laws, inclusion of tenancy clauses and subjection of union laws to the Nigerian Constitution. ${ }^{109}$

However, despite their subjection to state law, market laws contain some self-help clauses that clearly contravene the Constitution. Examples are the

105 A Lawal "Markets and street trading in Lagos" in T Falola and JS Steven (eds) Nigerian Cities (2004, Africa World Press) 237.

106 Report of the Zangon Kataf (Market) Riots Judicial Commission of Inquiry, June 1992, at 1 and at 52 , para $87(\mathrm{v})$.

107 See, eg, the Ogbete Main Market Traders' Association bye-laws.

108 Sec 13 of the OMMATA Constitution provides for a legal practitioner to act as legal adviser.

109 Constitution of the Federal Republic of Nigeria 1999, as amended. 
power of unions to restrict movement of people in the market, lock up the shops of recalcitrant traders and prevent members from resorting to regular courts without exhausting the remedies of market tribunals. Interestingly, state law tolerates these constitutional deviations because they contribute to peace and security in markets. This tolerance demonstrates the flexibility of bottom-up peacebuilding over rigid adherence to the rule of law favoured by the liberal peace. ${ }^{110}$ It further demonstrates the need for a symbiotic approach to normative interaction, as evident below.

\section{Jurisdiction interface}

State law's symbiotic interface with market laws is evident in traders' prohibition of police intervention in market disputes. In fact, the police rarely enter a market without obtaining the permission of union leaders, or at least informing them. As a union leader in Warri stated, "we prefer to call the police ourselves. If any policeman wants to make an arrest in the market, he must first report to me ... The army and police personnel guarding the market all report to me." 111 Where traders refer a dispute to the police or the courts without exhausting the remedies in their market tribunal, they could be forced to withdraw the complaint or even be fined. Indeed, some union officials in Enugu, Lagos and Warri asserted that the police routinely defer to union jurisdiction in non-criminal trade disputes. This deference recognizes the grassroots dispute resolution style of market tribunals as more effective in peacebuilding than the bureaucratic style of state law. As an informant in Lagos stated, "When there's any problem in the market, we don't go to police station because their wahala (trouble) is too much". ${ }^{112}$

\section{Dispute resolution interface}

Generally, the peace committee of a market union constitutes its tribunal. Although these tribunals restrict their jurisdiction to civil matters, they routinely adjudicate disputes involving criminal elements such as stealing, fraud and fighting. However, not all disputes reach the tribunal, since many disputes are settled on the spot by fellow traders or informally by union officials. For disputes which reach the tribunal, the grievance procedure is fairly standardized. Usually, a complainant registers a dispute with the secretary or chairperson of a union or the chair of its peace committee. There is no clarity on registration fees. Some officials admitted they charge fees on a case-by-case basis; some affirmed they adhere to fees prescribed in their constitutions, while others denied that they charge fees. ${ }^{113}$

$110 \mathrm{JH}$ Peterson “'Rule of law' initiatives and the liberal peace: the impact of politicized reform in post-conflict states" (2010) 34/1 Disasters 15.

111 Interview with Comrade Lucky Otu, president of the Ogbudu Market Traders' Association, Delta State, 14 February 2017.

112 Interview with Steven Edeokoye at Idumota Market, Lagos, 3 February 2017.

113 Chukwuemeka Azubike, chair of the Enyimba Line Traders' Association, Aba, related an intriguing system of registration: disputants pay a $\$ 5000$ fee each and the losing party 
After a dispute is registered, the concerned official constitutes the tribunal and summons both the complainant and defendant on a certain date and time. The tribunal sits with at least two members and can have up to nine members, as is the case in OMMTA. Generally, tribunals favour an odd number to avoid a split decision. For example, the peace committee of the Association of Medicine and Pharmaceutical Product Dealers, Onitsha has seven members. ${ }^{114}$ Where the tribunal finds a party guilty, it may impose a fine. However, decisions may include specific performance of a contract, refunds, repayment of loans and apology.

A losing party may appeal to the disciplinary committee of the central union or zone, depending on the level of peace committee that decided the dispute. For example, in Enyimba Market Aba, which has ten zones, appeals lie to the Abia State Market Amalgamated Traders' Association (ASMATA), the umbrella union of all markets in Abia State. The appeal body of ASMATA may summon the peace committee of the concerned zone to explain its proceedings. However, appeals are relatively rare and traders who appeal without serious merit may have their fine increased. If traders refuse to pay fines or comply with orders, "their shops will be locked until the money is paid with an addition of one thousand naira respectively". ${ }^{115}$ A recalcitrant trader may also be suspended from trading for upwards of three months. On the face of it, nothing stops a trader from appealing to the regular courts. However, such an appeal could rob a trader of social legitimacy. As an informant bluntly put it, "you cannot fight the market". ${ }^{116}$ Moreover, market tribunals have a reputation for fairness. Indeed, the chairman of the Ogbete Market Peace and Disciplinary Committee (OMPDC) boasted that OMPDC has a 95 per cent success rate. He claimed that in the seven years to 2017, only three out of hundreds of cases had gone to the courts. He went to great lengths to explain that OMPDC's rulings are meticulously written and the bases of its decisions are made very clear. He also affirmed the assertion of union leaders in Aba, Lagos, Port Harcourt and Warri that state courts recognize the decisions of market tribunals as enforceable arbitral awards.

Significantly, the records of proceedings of many market tribunals increasingly emulate the style of state courts. As I show in the next section, this emulation, along with the growing sophistication of market laws, is significant for indigenous law's adaptation to state law.

contd

forfeits this sum. The winning party may "settle" members of the peace committee with any amount he deems fit from the refund.

114 Focus group discussion in Onitsha on 21 February 2017. Views on the peace committee were expressed by its chair, Uche Eze, chief whip, Uzoma Nwadike, and a trader, Chinekebuka K. Obichie.

115 Sec 4 of the OMMTA bye-laws titled "Under peace committee".

116 Interviews with Olabisi Falodun-Onagoruwa and Adeoye Rahman, secretary of the Agarawu Traders' Association (Hardware Zone) of Idumota Market, Lagos, 27 February 2017. 


\section{Significance of state law's interface with market laws}

As far as normative interaction in sub-Saharan Africa is concerned, state law represents the colonial legal heritage. Over a century of this heritage and its accompanying culture has "Europeanized" many Africans, ${ }^{117}$ seeing them embrace Western culture to the detriment of indigenous law. Thus, in southern Nigeria, market laws, which ought to represent indigenous law, have so adapted to socio-economic changes that they are faintly remembered by elders, hardly known by traders and overshadowed by state law and its cultural paraphernalia. For example, the OMMTA headquarters is called "White House", an obvious reference to the residence of the president of the United States of America. The chairman of OMPDC referred to himself as the chief judge of Ogbete Market. He showcased how OMMTA has a president and a house of representatives, structures which mirror Nigeria's Western-inspired system of governance. The increasing disappearance of indigenous market laws demonstrates the value of an adaptation framework of normative interaction. As scholars have pointed out, there is a close link between normative interaction, peacebuilding and development. ${ }^{118}$

However, normative interaction, which is an indispensable component of state-building in post-colonial societies, generally follows a top-down approach, as evident in rule of law programmes. ${ }^{119}$ Significantly, a top-down approach characterizes the liberal peace model, which tends "to concentrate on the contemporary", thereby excluding the historical background of the issues that cause conflicts. ${ }^{120}$ This argument is especially relevant in postcolonial societies like Nigeria, where indigenous law struggles to cope with revolutionary socio-economic changes caused by the transplantation of industrial legal systems on to agrarian political economies. As the analysis of indigenous trade laws in part three reveals, traders were forced to embrace these socio-economic changes, leading to adaptations in market laws, values and systems of trade. One of the consequences of these adaptation processes is the shift of market control from its communal and magico-religious based foundations to the state, thereby creating new power dynamics in market organizations. Despite this shift, however, peace in markets is still maintained through a system operating with the spirit of indigenous trade laws.

\section{CONCLUSION}

Peacebuilding is a holistic concept that encompasses conflict prevention. Accordingly, it requires a nuanced approach that takes into consideration

117 LFJ Lugard The Dual Mandate in British Tropical Africa (2013, Routledge; 1st ed 1922, Blackwood) at 79.

$118 \mathrm{~J}$ Mertus and J Helsing Human Rights and Conflict: Exploring the Links between Rights, Law, and Peacebuilding (2006, US Institute of Peace Press).

119 Mac Ginty "Hybrid peace", above at note 6 at 408.

120 Id at 406-407. 
the social, cultural, economic, religious and legal elements that affect human security. This is the context in which I have argued that peacebuilding will be improved if policies on the interaction of legal orders focus on the manner people adapt indigenous trade norms to legal, religious, political and economic changes in social fields. These trade norms operated on the principle of fairness, which my informants described as justice, uprightness and conscience. Even though colonial-induced changes have swallowed most of these norms, their spirit of fairness guides the evolution of market laws. Thus, an adaptation framework of normative interaction is better suited to peacebuilding than the liberal peace model, for the following reasons.

First, market organizations reveal a complementary relationship between market unions and the state. The liberal peace may miss this complementarity. In Mac Ginty's words, "[w]hile the liberal peace may be adept at top-down technocratic ministrations through national governments and ministries, local actors may be better placed to deal with aspects of peacebuilding that have emotional dimensions, such as reconciliation or tolerance". ${ }^{121}$

Second, scholars and practitioners increasingly find that peacebuilding is most effective and sustainable when it focusses on grassroots notions of peace and their underlying socio-economic dynamics. ${ }^{122}$ Market tribunals in southern Nigeria symbolize grassroots notions of peace, and their sensitivity to socio-economic dynamics promotes peace among millions of traders. As many traders affirmed, police officers are not allowed in market disputes. Interestingly, the police force is the most visible feature of state power, a feature historically unknown to indigenous law. ${ }^{123}$ Police prohibition from market disputes thus reflects continuities in people's distrust of the culture of systemic violence brought by colonial rule. As an intriguing interface of market laws and state law, therefore, police exclusion from market disputes demonstrates the ineffectiveness of top-down peacebuilding.

Third, market organization in southern Nigeria demonstrates dialogue between state law and indigenous law. The symbiotic interface of state law and market laws is sustained by co-operative governance between market unions and state officials. For example, the president of OMMTA is the senior special adviser to the Enugu State governor on market affairs. His position is not unique, as the heads of most central market unions in Nigeria also play active roles in governance. These roles are notably in ministries of commerce, mining and environment, and departments such as the National Drug Law Enforcement Agency, Power Holding Company of Nigeria and Board of Internal Revenue. The roles of union leaders tacitly recognize the effectiveness of grassroots peacebuilding within the interface of state law and market laws.

121 Id at 408.

122 C de Coning "Understanding peacebuilding as essentially local" (2013) 2/1 Stability: International Journal of Security and Development 1.

123 EEO Alemika "Colonialism, state and policing in Nigeria" (1993) 20/3 Crime, Law and Social Change 187. 
Finally, an adaptive view of normative interaction unveils socio-legal realities that are literarily hidden in plain sight. It is common knowledge that African states continued using the legal structures instituted by colonial authorities. Other than the state-centric nature of these structures and their wholesale use of transplanted European laws, they are remarkable for their support to colonial transformation of Africa's political economy. This transformation includes changes in indigenous systems of land tenure, education, income generation, religion and philosophy. These socio-economic changes did not leave normative behaviour unaffected. In people's quest to reconcile indigenous laws with the pervasive changes occurring around them, they are compelled to adapt, especially to state law. Arguably, however, their adaptation struggles receive poor policy support due to the ways in which colonial legal transplants disregarded the value-laden dynamics of indigenous law. Faced with urbanization, individualistic profit values and absence of moral control by the extended family, traders replaced trust with receipts, deeds and notarized documents. Since law cannot be explained outside of the socioeconomic factors that inform human behaviour, studying the interface of state law and indigenous market laws could assist peacebuilding policies to be more holistic, more participatory and more locally-legitimate.

Ultimately, the interface of normative orders in post-colonial social fields of commerce demand scholarly interest. After all, trade and political control are like Siamese twins, while development underpins their relationship.

\section{CONFLICTS OF INTEREST}

None 